УДК: 330.519 .86

DOI: $10.24045 /$ et.2017.1.11

ЭКОНОМИКО-МАТЕМАТИЧЕСКАЯ МОДЕЛЬ И МЕТОДИЧЕСКИЕ РАЗРАБОТКИ

ОПТИМАЛЬНОГО ИСПОЛЬЗОВАНИЯ ВОДЫ ИСКУССТВЕННОГО ВОДОЕМА В ГОРНЫХ РЕГИОНАХ РЕСПУБЛИКИ УЗБЕКИСТАН

Х. Х. Хикматов

Х. У. Акбаров
Кандидат экономических наук

Самаркандский государственный

архитектурно-строительный

институт

стариий преподаватель

Самаркандский сельскохозяйственный

институт

2. Самарканд, Узбекистан

\title{
ECONOMIC AND MATHEMATICAL MODELS AND METHODICAL DEVELOPMENT OF OPTIMAL WATER USE ARTIFICIAL RESERVOIRS IN MOUNTAIN REGIONS OF UZBEKISTAN
}

H. Kh. Hikmatov

H. U. Akbarov
Ph.D.

Samarkand State Architectural and Civil Engineering Institute senior lecturer Samarkand Agricultural Institute Samarkand, Uzbekistan

\begin{abstract}
The purpose of setting objectives integrated development and management of water and land resources of mountainous regions of Uzbekistan with the help of economic and mathematical methods and models, and the use of the best approaches for solving this problem, and in the future to develop guidelines for the optimal use of water and land in the territory of an artificial body of water and protection against corrosion ground. The solution to these questions allows you not only to create new jobs, but also to accelerate the structural changes in the agricultural sector of the Republic of Uzbekistan. As well as the optimal use of water in the mountain regions of the country, will lead to the improvement of the cultivation of trees for the production of building materials (wood), eco-clean food products.
\end{abstract}

Keywords: model; economic-mathematical model.

Человечество для удовлетворения своих нужд искусственно формирует природно-антропогенные водные объекты - искусственное водоёмы, водохранилища и пруды, где вода накапливается и в после- дующем используется для разнообразных целей: орошения земель, рыболовства и рыбоводства, получения энергии и т. д.

Основная поставленная нами задача - разработать экономико- 
математическую модель и методические указания для оптимального использования накопленных вод через создание искусственных водоёмов.

Из анализа источников известно, что острый недостаток чистой питьевой воды испытывают жители 80 стран мира. Вода является источником жизни, а также важной материальной основой для социальноэкономического развития общества.

В конце 20 века в связи с водным кризисом появилось понятие экологический беженец. Во всем мире, в том числе в Узбекистане, дефицит воды стал одним из главных негативных факторов, с которым сталкивается человечество.

Особенно с ростом населения, а также в связи с развитием промышленности и сельского хозяйства спрос на воду постояно увеличивается.

В настоящее время проблема обеспечения водой является одним из важнейших факторов, непосредственно влияющим на устойчивое развитие общества и экономики.

В связи с этим рациональное использование водных ресурсов и их охрана имеют ключевое значение для достижения устойчивого развития региона.

Спрос на воду включает четыре основных компонента: сельское хозяйство, производство электроэнергии, промышленное использование и бытовое потребление.

Ежегодно зимой и весной в горных районах республики бесполезно протекает много кубометров воды. Для того, чтобы исползовать этот бесценый ресурс в сельскохозяйственной отрасли, была поставлена следующая задача - создать экономико-математическую модель искусственного водоёма, методику и программу для оптимального использования водных и земельных ресурсов на территории водоёма, методику защиты от коррозии земель в горных районах.

Для этого потребуется сбор необходимой информации для создания искусственного водоёма, а после этого разработка экономикоматематической модели для эксплуатации, разработка методических и технических указаний по исползованию водных и земельных ресурсов на территории водоёма и рекомендации полученных результатов аграрному сектору республики.

Аграрный сектор в настоящее время претерпевает радикальные преобразования, в том числе реструктуризацию и передачу больших государственных хозяйств в небольшие частные или арендованные фермерские хозяйства. Это создало ряд проблем. Фермерские хозяйства в настоящее время находятся в ведении новых людей, которые не имеют обширного сельскохозяйственного опыта, эффективного производства продукции растениеводства и орошения земли.

В целях воплощения в жизнь данной идеи предполагается рассмотреть следующие задачи: разработать экономико-математическую модель для создания искусственного водоёма, методику и приложения для организации растительных плантаций на территории искусственного водоёма, методику защиты от эрозии земель, создать 
условия для восстановления флоры и фауны и эффективного использования водных и земельных ресурсов территории искусственного водоёма.

Экономико-математическая модель задачи имеет следящий вид:

Целевая функция

$Z_{\text {max }}=\sum_{i=1}^{k} C_{i} X_{i}$

Система ограничений

$$
\sum_{i=1}^{k} \sum_{i=1}^{k 1} \sum_{i=1}^{k 2}\left(D_{i} S_{i}+R_{i}\right) \leq Q
$$

$\mathrm{Q}$ - тах объём воды;

$$
\begin{gathered}
D_{i} \geq \theta, S_{i} \geq \theta, R_{i} \geq \theta \\
\mathrm{X}_{i}=D_{i}+S_{i}+R_{i}
\end{gathered}
$$

$C_{i}$ - прибил единиц объёма воды i - его периода;

$$
C_{i} X_{i} \geq H
$$

$\mathrm{H}$ - ожидаемый прибили;

Процесс решения задачи выполняется с помощи ППП GAMS (General Algebraic Modeling System), которые используется для решения экономикоматематических задач по всему миру [3]. Таким образом, мы можем получить конкретные численные результаты для оптимального использования водных ресурсов в горных регионах Республики Узбекистан.

\section{Библиографический список}

1. Ашманов С. А. Математические модели и методы в экономике. - М. : Издательство МГУ, 1980.

2. Замков О. О., Толстопятенко А. Б., Черемных Ю. Н. Математические методы в экономике. - М. : ДИС, 2000.

3. Akbarov H., Urdushev Kh., Raximov Kh. Regional analysing of production fruitvegetables and grapes in Uzbekistan // Сборники конференций НИЦ «Социосфера». - № 39. - 2014. P. 124-128.

\section{Bibliograficheskij spisok}

1. Ashmanov S. A. Matematicheskie modeli $\mathrm{i}$ metody $\mathrm{v}$ jekonomike. - M. : Izdatel'stvo MGU, 1980.

2. Zamkov O. O., Tolstopjatenko A. B., Cheremnyh Ju. N. Matematicheskie metody v jekonomike. - M. : DIS, 2000.

3. Akbarov H., Urdushev Kh., Raximov Kh. Regional analysing of production fruitvegetables and grapes in Uzbekistan // Sborniki konferencij NIC «Sociosfera». № 39. - 2014. - P. 124-128.

(C) Хикматов $X . X$., Акбаров Х. У., 2017. 